\title{
TOPONYMY, TAXONOMY AND PLACE
}

\author{
Explicating the French concepts of presqu'île and péninsule
}

[Received February 11th 2015; accepted June 17th 2015 - DOI: 10.21463/shima.10.1.04]

\author{
Christian Fleury \\ University of Caen Normandy <fleury.cote@wanadoo.fr> \\ Benoît Raoulx \\ University of Caen Normandy <benoit.raoulx@unicaen.fr>
}

\begin{abstract}
This article discusses the concepts of and differences between the French terms presqu'île (almost island) and péninsule (peninsula) and their toponymic uses. The discussion raises a number of questions including how and why particular places are named presqu'île or péninsule. We will first focus on examples located in the French Southern and Antarctic Lands and then in mainland France. These two case study areas are complementary. The first example, the Kerguelen Islands in the Southern Indian Ocean, has been the site of a recent attempt to normalise place-naming for the purpose of asserting sovereignty. The second one, the Cotentin, is a part of Normandy, whose long history of human inhabitation has provided several layers of toponymy. Finally we refer to the use of the term presqu'ile in the context of urban riverfront revitalisation. In the latter usage, cities try to promote their locations by using the image of the peninsular almost island'. The reflections presented in the article show the complexity involved in naming and interpreting locations as either peninsulas or 'almost islands'.
\end{abstract}

KEYWORDS: Peninsula, péninsule, presqu'île, almost island, toponymy, Kerguelen Islands, Cotentin

Introduction: the relevance of defining the fields of péninsule and presqu'île

The word presqu'île is peculiar to the French language. In other Latin languages - like in Spanish (península) and Italian (penisola) - as well as in English, derivants of the Latin term paeninsula are used to denote a piece of land surrounded by water on three sides and connected to a mainland. While the term derives from the Latin terms paene 'almost' and insula, 'island', this sense is not foregrounded in current usage (given Latin's decline as an intelligible language). This is not the case with regard to the French term presqu'île, also used to refer to such areas, deriving as it does from two (currently used) terms presque ('almost') and île ('island'). The linguistic overlap between the two terms was attested to in the famous Encyclopédie compiled by Diderot and D'Alembert and published in the 18th Century (1751-1772), where presqu'île (or presqu'isle) is defined as the same as peninsula. In some Scandinavian languages however, like Danish, the word for peninsula is halvø (halvö in Swedish, halvoy in Norwegian, hálvoggj in Faeroese), a term that combines ø ('island') and halv ('half). This is the similar in German with halbinseln. Presqu'île and halvø are close in sense and their meaning is clear for native language speakers, as it is a 
combination of two common words. However, in Scandinavian and German languages the term has the same sense as peninsula in English, referring to anything from a small piece of land to a part of a continent stretching into the sea. In Danish, for example, Helgenæs ${ }^{1}$ in Djursland is classified as a halvø but also the Arabic peninsula (den arabiske halvø).

Our aim is to go beyond the taxonomy of landscape and our study examines the geopolitical and cultural dimensions of naming and describing space. On one hand, the state tends to normalise the use of terms through taxonomy and toponymy, an exercise that is related to the ability to normalise space through maps and thereby attempt to to control it in order to produce a territory. This process is relatively recent and is associated with the rise of nation-states, which are concerned with border delimitations and mapping to assert their legitimacy. On the other hand, place-naming shows the flexibility of local cultures, where the toponymy results from different cultures through history and which define the landscape through their own categories, thus producing a place $e^{2}$. In order to explore this idea we focus on different examples from two French speaking areas: the Kerguelen Islands, which has been recently colonised, and the Cotentin, which shows a strong local identity constructed through a long history. Finally, we refer to presqu'îles in rivers and harbours, showing recent attempts by local governments to promote particular spaces by associating them with islands.

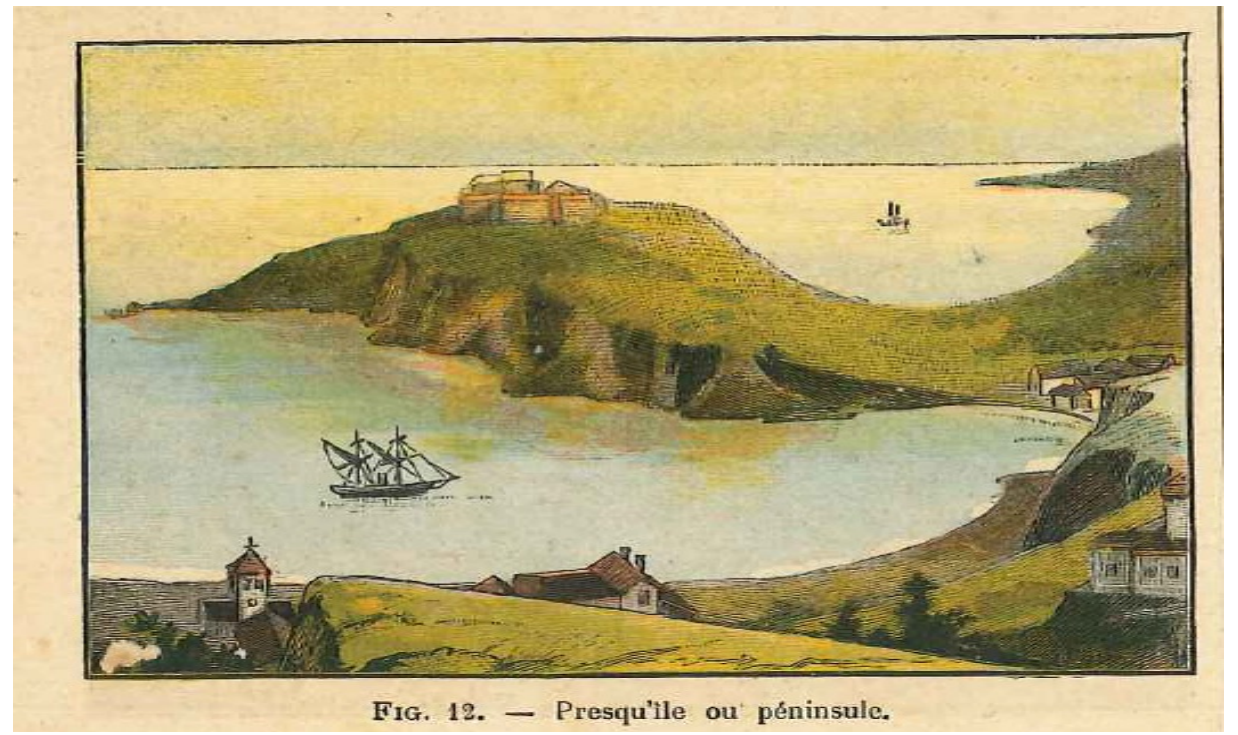

\footnotetext{
${ }^{1}$ In this place name, the word nces refers to a promontory or presqu'ile similar to that in the name of Nez de Jobourg in Normandy (as discussed latter in the article).

${ }^{2}$ We refer to two different concepts in geography, territory, which mainly refers to power and control of a space from the State) (Agnew, 2003) and place, which refers to the culture and the experience of space by individuals and a population (Tuan, 1977). The two dimensions can be combined in a dialectical way to analyse situations.
} 
Figure 1 - a representation of a presqu'île or péninsule in a French schoolbook. (Source: Poncin, c1910: 4)

\section{The use of péninsule and presqu'île: the limits of a taxonomic approach}

To support our discussion, we first refer to a section of a schoolbook from the early 2oth Century that was used by millions of French children to learn the basics of geography. The first part is dedicated to defining the main terms used in physical geography, beginning with words related to the sea. Despite the fact the book's objective is very normative, the notions of presqu'île and péninsule are rendered as interchangeable (cf Figure 1). In fact, the maps from the book show and describe similar areas with different terms: the presqu'île ranges from a small area like that pictured below (which aims to represent the notion) to a subcontinent, ie India). Some areas are listed under category of presqu'île but are named as péninsules, including the péninsule ibérique (the Iberian peninsula), péninsule italique (the Italian peninsula), and the péninsule scandinave (the Scandinavian peninsula).

Another example of this uncertain definition is apparent with regard to Greece, identified as presqu'île héllénique in the text but as péninsule hellénique on the map (1910: 38-39). However, it is possible to distinguish a hierarchy of size in that a péninsule is bigger than a presqu'île. A presqu'île seems to be seen from the sea while a péninsule seems to be perceived from a continental viewpoint. Péninsule refers to a mainland area stretching into the sea, such as la péninsule coréenne (the Korean peninsula), la péninsule ibérique (the Iberian peninsula) and la péninsule de Kola (the Kola peninsula). But in common language use it is unusual to attach the word péninsule to the place name as such. There are many examples where the place name refers to a region or large area: Crimée (Crimea), Basse Californie (Baja California), Kamchatka and Bretagne (Brittany). French speakers usually say Gaspésie (Quebec) rather than péninsule de Gaspésie and say Floride (Florida) rather than péninsule de Floride. However, in the past, such usage seems to have been more flexible. Florida, for instance, is named and represented in early French maps of North America as a presqu'ile (Figure 2) but the name Florida encompassed a large area, which could even include part of the Louisiana territory, which was named in the late 17th Century by the French. It may be possible that the shift from presqu'ile de Floride to Floride is related to political changes in North America. Florida came to refer to a smaller area, a territory, and latter a state, which today corresponds to a large extent (except the 'panhandle', on the Western part) with a topographical entity.

In North America, the Inventaire toponymique du Québec defines the péninsule as "an extension of the continental body into the sea" and a presqu'île as "land almost surrounded by sea [but] linked to the neighbouring shore" (Commission toponymique du Québec, nd authors' translations). Some topographic categories have been used directly as place names that can be termed toponymes génériques (generic place names) (Morissonneau, 2008). This place-naming is related to the colonisation. Many places have been named with reference to distinctive topographical features. Presqu'̂̂le is quite common as a place name in areas colonised by the French in North America, for example Presqu'ile Provincial park in Ontario (without the accent circonflexe), Presqu'isle in Maine, USA, where the course of the river Arostook makes a peninsula (isle is the old form of spelling île in French), and Lac de la Presqu'île in northern Québec ('Peninsula Lake' - rather than la

Shima: The International Journal of Research into Island Cultures

Volume 10 Number 12016 
Presqu'île du Lac [Lake Peninsula]). By contrast, in France, the term presqu'île is never used without referring to another place name, often a town or a village (ie presqu'île de Giens - in the Southeast of France - or presqu'île de Crozon, in Brittany), except in the case of cities, as will be discussed later in the article.

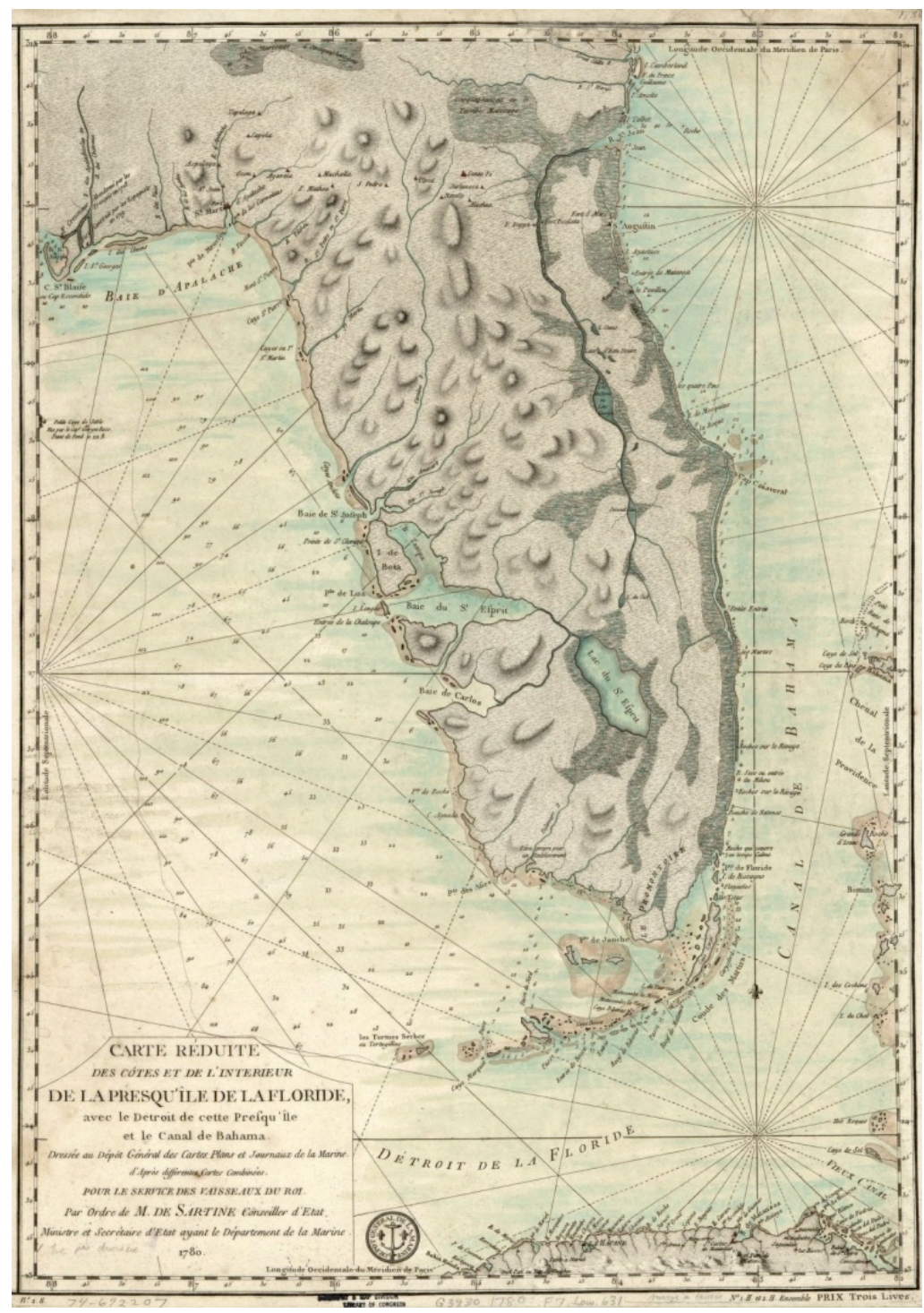

Figure 2 - French map of Florida from 1780 with presqu'île designations. ${ }^{3}$

${ }^{3}$ Carte réduite des côtes et de lintérieur de la presquîlle de la Floride, avec le détroit de cette presquî̀le et le canal de Bahama. Dressée au Dépôt général des cartes, plans, et journaux de la marine, d'après 
In the context outlined above, size thresholds are not the most significant factor in determining the designation of an area as either a presqu'île or péninsule. Relational significance is a more crucial aspect and can be hierarchical in that a presqu'ile can be defined in relation to smaller or bigger topographical entities. Two examples in different parts of the Francophone world exemplify this, the Kerguelen Islands in the southern Indian Ocean and the Cotentin Peninsula in north-western France.

\section{The Kerguelen Islands: a laboratory in distinguishing presqu'île and péninsule}

The Kerguelen Islands (with an aggregated land area of $7052 \mathrm{~km}^{2}$ ) are an archipelago located in the Indian Ocean at $49^{\circ} 21^{\prime}$ South and $70^{\circ} 13^{\prime}$ East and are administered as part of Terres Australes et Antarctiques Françaises (TAAF) (the French Southern and Antarctic Lands). The only settlement is Port-Aux-Français, a research station created in 1949. Due to their recent occupation, these uninhabited islands can be considered as a laboratory for place nomenclature with particular regard to the hierarchy of presqu'île/péninsule. Since their discovery in $\mathbf{1 7 7 2}$ by the French sailor Yves Trémarec de Kerguelen, who did not acknowledge the insularity of the land and named it France Australe ('Southern France'), the islands have been explored by several expeditions. The coast of Kerguelen's main island - Grande Terre - is characterised by many fjords, peninsulas and smaller, fringing islands. Following their discovery, the islands were used for seal and whale hunting, mainly carried out by Americans and later by an Anglo-Norwegian company. After a period of uncertain sovereignty, the French asserted their control after the First World War. Inspired by the example of the British colonisation of the Falkland Islands, attempts were made to develop settlements in 1913 and 1927 orientated to sheep farming, undertaken by a company from Le Havre, but these both failed (Raoulx, 1993).

Despite the fact that there has been no permanent settlement, the archipelago's toponymic history is quite complex. Many places have been renamed several times by seafarers, scientific expeditions and seal hunters (Delepine, 1973). The best-known expeditions were the ones conducted in 1913 by Captain Rallier du Baty, who was a major contributor to mapping the coastline (du Baty, 1922; Loranchet, 1922) and by Egard Aubert de la Rüe, a geologist and geographer specialising in islands, in 1928 and 1930. But it was only in the late 196os and early 1970s that the official toponymy was extended and normalised after a systematic mapping of the islands was carried out by the Institut Géographique National (IGN) to produce the 1:100 ooo reference map (Commission territoriale de toponymie, 1973). Due to the complex shape of the coast, the Commission decided to name the space according to size criteria. As it can be seen on the map (Figure 3), the term péninsule is used to refer to the largest pieces of land, even when, due to their relatively small size, they would probably been considered as presqu'îles elsewhere.

The main island is referred as the mainland (Grande Terre) and is presented as something of a 'micro continent' upon which péninsules and presqu'îles can be designated:

différentes cartes combinées. Pour le service des vaisseaux du roi (map) Paris : Dépôt général de la Marine, 178o. Online at: www.loc.gov/ressource/g3930.ar162100 - accessed May 15th 2015.

Shima: The International Journal of Research into Island Cultures

Volume 10 Number 12016 
Finally, taking into account the extreme indented coastline of the Kerguelen Islands, the commission decided to give the name péninsules to the shapes that would have been called presqu'îles in other places and the name gulfs to indentations that would have been simply considered as bays - such as the case of Péninsule Courbet and the Golfe du Morbihan. (Commission de toponymie, 1973: 4 - authors' translation)

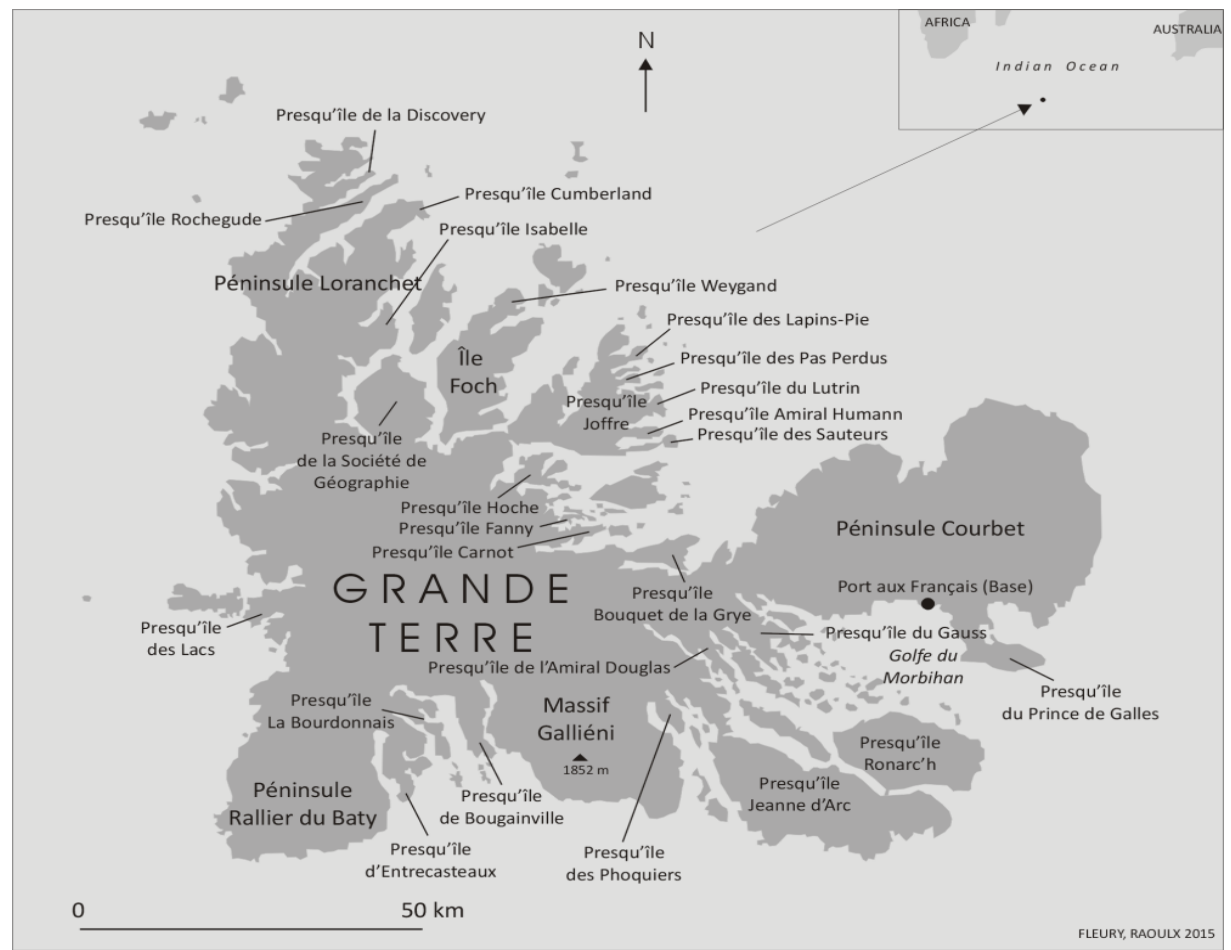

Figure 3 - The Kerguelen Islands and designation of presqu'îles and péninsules (derived from Institut Géographique National map [undated])

The word péninsule is used for larger land areas (with few exceptions like Presqu'île Jeanne d'Arc, in the south-east, where the isthmus is very narrow - see Figure 3). In fact, size, shape and hierarchy combine to qualify a space as a presqu'île. The Presqu'île Jeanne d'Arc is not a péninsule because of the very narrow and flat neck of land linking it to Grande Terre (measuring about half a kilometre across), which used to be a place to haul boats from one side to the other ${ }^{4}$. The Presqu'île Jeanne d'Arc was originally named Péninsule Joffre by Rallier du Baty during his 1913 expedition (Rallier du Baty, 1922). The change of designation reveals both the complexity of place-naming and the geopolitical issues

\footnotetext{
${ }^{4}$ In fact, this isthmus is called the Halage des Swains (a translation of Swain's Haulover, a name given to it by seal hunters in the 19th Century).
} 
involved. In 1915 the name Joffre (referring to Marshal Joffre, considered as one of the main figures in the Allied victory during the World War I) was given by the Service Hydrographique de la Marine, the French naval hydrographic service, to another presqu'île on the northern shore that had been previously named the Bismarck Halbinsel (Bismarck peninsula) by the German Gazelle scientific expedition in 1874. During the First World War the French started to rename the region's toponymic features, rejecting many German names. This resulted in two places in different locations using the name Jeanne d'Arc: Port Jeanne-d'Arc, on the south-eastern coast, where a whaling factory was established in 1909 that operated for few years (the very French place name was chosen by the Anglo-Norwegian company that opened the factory, presumably in an attempt to please the French authorities) and the Presqu'île Jeanne d'Arc in the north. In order to avoid this mismatch, the Commission switched the names of the two presqu'iles. The former Presqu'île Joffre in the South became the Presqu'île Jeanne d'Arc and the former Presqu'île Jeanne d'Arc in the North became the Presqu'île Joffre, as it is today (Figure 3).

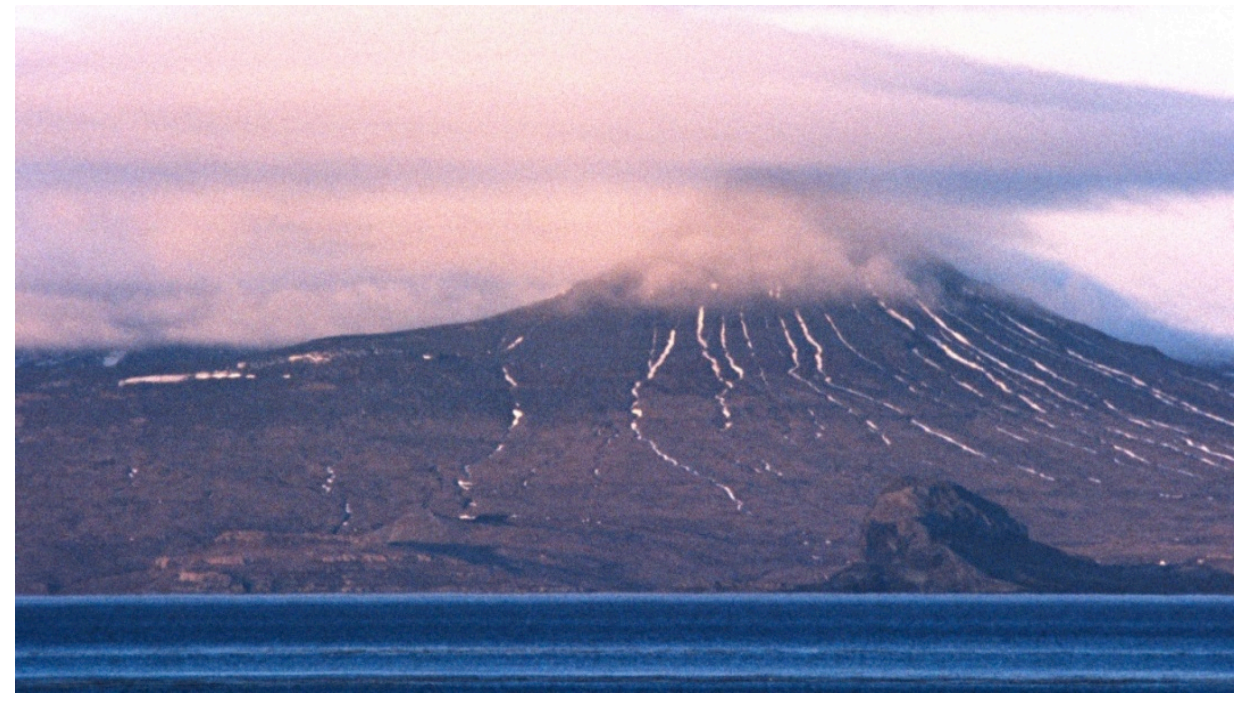

Figure 4 - Presqu'île Ronarc'h and the Mont du Pouce (744 m.) at sunset, Kerguelen Islands. (photo: B. Raoulx, 1986.)

At the second level, the word presqu'île was chosen to categorise pieces of land stretching from a péninsule on Grande Terre, or even from another presqu'île, into the sea. Thus, the presqu'île Joffre includes five other named presqu'îles. The second largest island, île Foch, in the northern part of the archipelago, is the only other space with a presqu'île (presqu'île Weygand). Many spaces do not have a place name (ie a number of places on the Western coast) but could be also named as presqu'iles. Others are named according to the topography - usually mountains - rather than using the term presqu'ile. For example, the area once known Péninsule Galliéni is now officially called Massif Galliéni (the highest point of the archipelago at 1852 meters) (cf. Figure 3), in reference to the topography. In the case of Kerguelen Islands, the word presqu'île or péninsule is part of the full place name and cannot be used without the anthroponym attached to it (ie Courbet, Rallier du Baty, Loranchet). 
Moving the discussion back to the French mainland, the example of Cotentin, in western Normandy, provides further insights into defining a presqu'île.

The example of Cotentin: a rich variety of names for coastal indentations

The Cotentin (a name that derives from the town of Coutances) is an isolated area of land in northwestern France (Figure 6) that is generally characterised as a presqu'île by its inhabitants. Located on Cotentin's northern coast, the main city, Cherbourg, has long been a strategic harbour for the French Navy. In recent decades the Cotentin has come to be commonly referred to as a presqu'île du nucléaire ('nuclear peninsula') on account of the location of two nuclear facilities in the area (the waste recycling unit at La Hague, operated by the Areva company since 1960, and the Flamanville nuclear power plant, established in 1983, which is currently due to be extended).

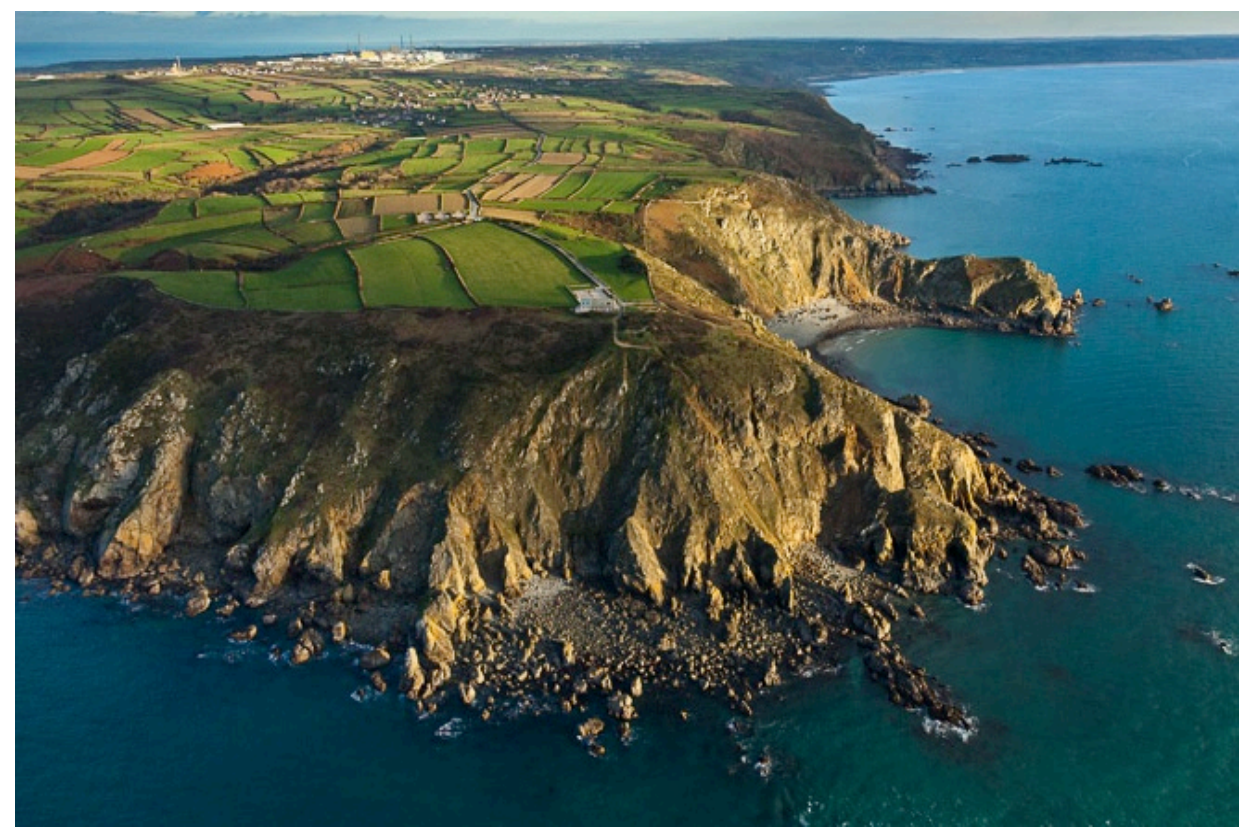

Figure 5 - Aerial picture of La Hague: in the foreground, the Cap de la Hague, in the background, the Nez de Jobourg. At the rear, on the left side, the nuclear waste recycling plant operated by Areva. (Photo: Francis Cormon.)

The Cotentin is connected to the rest of Normandy at its southern end by an area of low marshland that is often flooded in winter. This landscape was strategically utilised in 1944, during World War II, when the German army disrupted the marsh drainage system, effectively cutting off the Cotentin from the mainland in an attempt to prevent American forces from advancing from their landing places. ${ }^{5}$ The Cotentin is also significant for the

\footnotetext{
${ }^{5}$ As a result, many American parachutists drowned during the D Day invasion in June 1944.
} 
many different names given to small pieces of land projecting into the sea, including cap, pointe, nez or La Hougue. The variety of names identified above reveals the history of the Cotentin. Cap and pointe are part of a common French nomenclature but the appellations nez and La Hougue derive from the Scandinavian presence in Normandy during the Middle Ages. (Nez is a Norse term that has been rendered as ness in Great-Britain, for example, Tarbat Ness in Scotland, and -nces or -nes is also present in many Scandinavian place names today.) The Nez de Jobourg is the best known example but others can be found along the coast of the Norman mainland and in the Channel Islands (as in the case of Grosnez in Jersey) (Lepelley, 2002). A fourth type is exemplified by La Hougue, a place name that derives from the Norse haugr (elevation). It is probably a former islet connected to the mainland by a tombolo (bar) and is not considered as a presqu'île by the local inhabitants ${ }^{6}$.

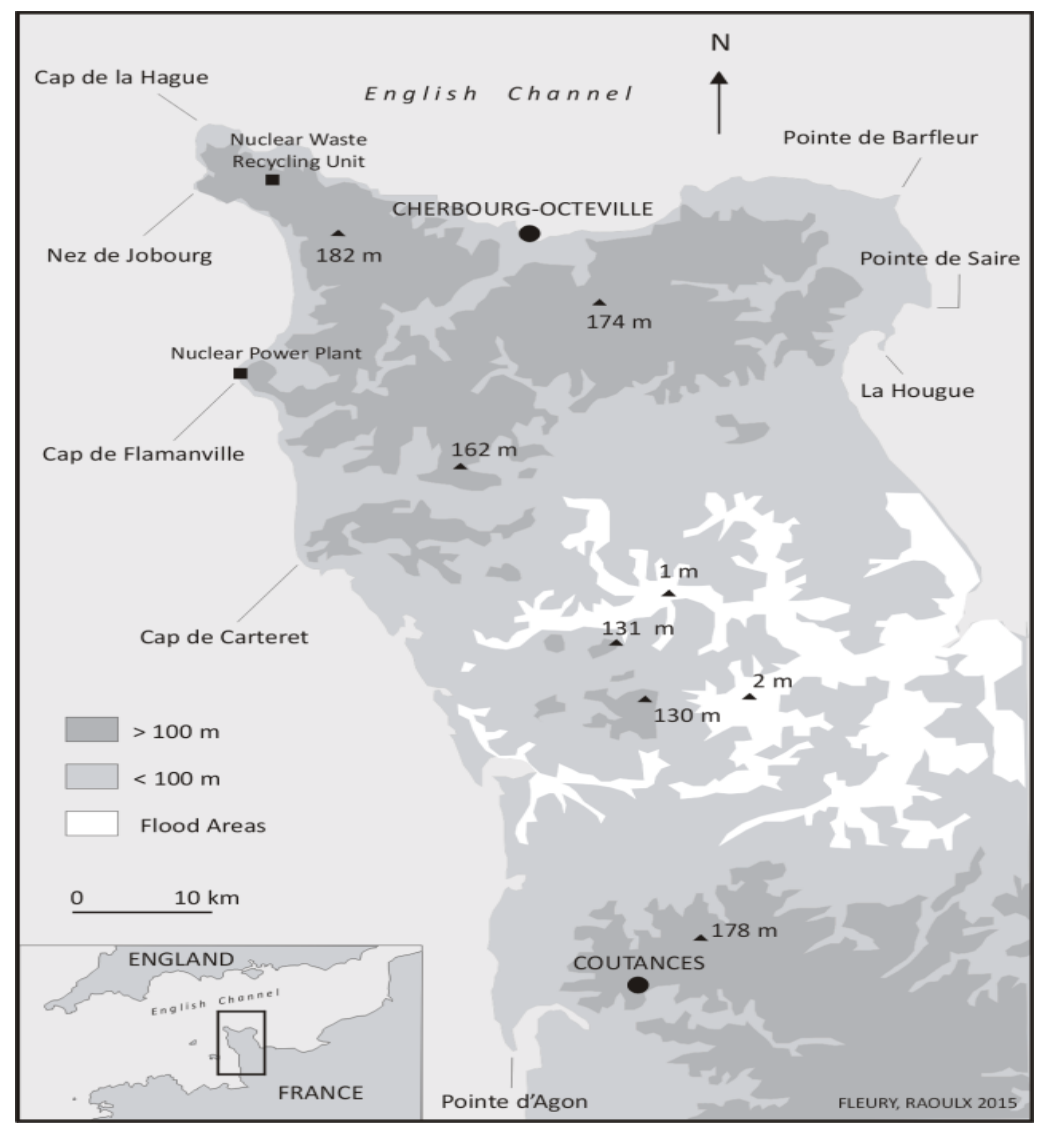

Figure 6 - Map of the Cotentin peninsula. ${ }^{6}$ A change of the topography doesn't mean a change of name. For example, in Brittany, the île Tudy
became connected to the Mainland in the mid-19th Century but has kept its island name.

Shima: The International Journal of Research into Island Cultures

Volume 1o Number 12016

-16 - 
The Cotentin has also been promoted as a tourist destination by the slogan Presque une ile ('Almost an island'). The latter term underlines the extent to which the image of an island is nowadays considered as an efficient hook in destination marketing. Such allusive references to islands are even more obvious in producing new urban spaces, as in the case of the riverfront projects discussed in the following section.

\section{River and harbour presqu'îles}

The word presquîle is often used along riverbanks, such as on the Seine River between Rouen and Le Havre, in Normandy. Here the river meanders and the spaces in these turns are often identified as presqu'îles. ${ }^{7}$ But presqu'île is also a place name found in the cities, such as la Presqu'île at the confluence of Rhône and Saône rivers in the city of Lyon. Presqu'ile is also a place name often found in industrial harbours, either referring to islands artificially connected to the riverbank or else areas of riverbank excavated to open docks. However, due to changes in port trade and activity many of these now comprise vacant areas located close to urban centres. In North America and Europe many formerly industrial riverfronts have been redeveloped and have become the sites of ambitious urban revitalisation projects.

In France, in particular, the so-called presqu'îles are becoming part of new urban districts integrated into the downtown cores. In this context, the term presqu'iles - conveying the image of (almost) islands - has become a particular type of place name and contributes to promoting new vision of cities. In Rouen, on the industrial left bank of the Seine river, for example, the Presqu'île Rollet (a former island connected to the riverbank in 190o) (Figure 7) has been renamed La Presqu'île, removing the former name's previous association with industry:

Symbolic of the reconquest of the left bank and representing the first stage towards the Flaubert Eco-Neighbourhood, the Presqu'ile comprises a magnificent site dedicated to walking, leisure and relaxation. A space that will be even more appealing with the summer coming... Inaugurated in 2013, the Presqu'île, formerly known as the Presqu'île Rollet or 'Coal island' offers 15 hectares for walking and leisure activities along the river. (CREA, 2013 authors' translation) ${ }^{8}$

\footnotetext{
${ }^{7}$ The tradition of boat traffic across the river has hindered the development of bridges and today there are only three bridges connecting the two banks between Rouen and Le Havre, the most recent one being the Pont de Normandie, near Le Havre, which opened in 1995. The first bridge to link the two banks, the Pont de Tancarville, was completed in 1959. Some ferries operate across the river in different places. The inhabitants consider the water as a border - de l'autre côté de l'eau ('on the other side of the water') is a traditional expression used by the local residents to refer to the opposite bank.
}

${ }^{8}$ See Jastrzebska (2014) for illustrations and overview.

Shima: The International Journal of Research into Island Cultures

Volume 10 Number 12016 


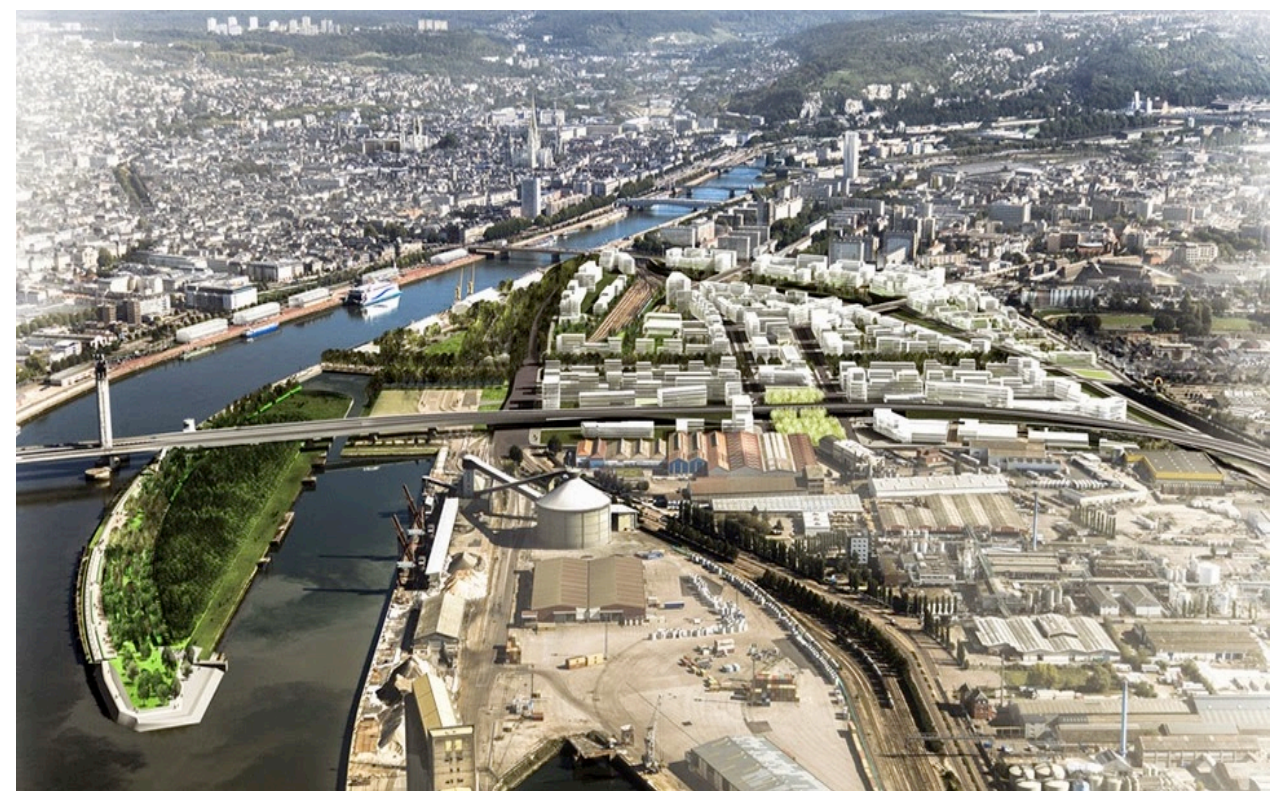

Figure 7 - Rouen, Normandy: Visualisation of Presqu'île park site (left of image). (Source: Atelier Jacqueline Osty and Associates.)

In the city of Caen, the presqu'île industrialo-portuaire ('industrial harbour peninsula') was created in 1857 as a consequence of the completion of the city's canal system. Running parallel to the Orne river, it provided easy access to Caen harbour, which is located $13 \mathrm{~km}$ from the seashore. ${ }^{9}$ The activity in these docks declined during the early-mid 2 oth Century and the relocation of infrastructure further down the canal and on the seashore from the 1960 s on, together with the closure of the steel factory in 1993, have left vacant areas ('brownfields'). The current revitalisation project aims to create a new neighbourhood. It has similarities with Rouen's redevelopment and the presqu'île désignation functions as a placename of its own. As in Rouen, the rhetoric of an (almost) island is used to promote the city.

\section{Conclusion}

Even where there is a difference in size, the nature of the distinction between presqu'ile and péninsule is far from evident. The discussions in this article allow us to observe that uses of the terms presqu'île and péninsule exemplify the difference between a normative approach - the attempt by scientists and officials to describe and order the landscape for

\footnotetext{
${ }^{9}$ It is strictly speaking, a long island stretching from Caen to the coast, but the inhabitants of Caen see it as a presqu'île. Furthermore, two short canals between the river and the main canal have recently been built to prevent flooding; one of them is located in Caen, where the revitalisation project is taking place.
} 
constructing a nomenclature - and the 'sense of place' as it is experienced by groups living in a location. Our discussion first referred to two case studies, the Kerguelen Islands and the Cotentin. These show the opposition between two models of toponymy. The Kerguelen Islands have been occupied recently and discontinuously. Our case study of these islands reflects the ability of the state to impose a norm in place-naming through mapping and shows how, in turn, the place-naming strengthens territorial control. This $e x$ nihilo toponymic construction is interesting for revealing ideological and geopolitical issues. By contrast, place-naming on the Cotentin results from the long and flexible construction of toponymy by different cultures and societies across history, the space effectively being a palimpsest. In this case, the sense of presqu'îléité ('presquîleness') combines historical depth and a cultural relation to the landscape (perception of the sea and relative isolation, in the French context). The third example - the riverfronts - shows how the presqu'île place name is an artefact for promoting particular identities for areas of cities, built on the appeal of an island and its adjacent waters. In this case, the presqu'ile is a sort of oxymoron: within the city, accessible, but associated with the sea and with the rêverie of being on an island.

The notion of presqu'île is thus far more complex than the péninsule. The latter term refers primarily to a standard nomenclature, despite the lack of clear definition, and the term does not have the allusive richness of presqu'île. The sense of place can be expressed through the notion of presqu'île - a smaller space strongly attached to the water - but not through the péninsule (the sense of place referring to other categories of spatial perception and culture). This dimension stresses the differences between small and big islands. The smaller the island is the more 'island' it appears (îleité in French - 'islandness'). Similarly, the presqu'île is more a presqu'île when it is smaller (presqu'îléité). In any case, both péninsules and presqu'îles show how place-naming and taxonomy can be a significant dimension of the relation to space; and the issues involved encompass both geopolitical dimensions and more sensitive cultural dimensions.

\section{BIBLIOGRAPHY}

Agnew, J (2003) Geopolitics: re-visioning world politics, London: Routledge

Aubert de la Rüe, E (1968) ‘Remarques sur la toponymie des îles Kerguelen’, Taaf n42-43: 12-41

Commission territoriale de toponymie avec le concours de Mme G.Delépine (1973) Toponymie des Terres Australes, Paris: TAAF (éd Documentation française)

Commission toponymique du Québec (nd) 'Inventaire toponymique du Québec': http://www.toponymie.gouv.qc.ca - accessed November 12th 2014

Communauté d'agglomération Rouen-Elbeuf-Austreberthe (CREA, Rouen regional district) (2013): http://www.la-crea.fr,ecoquartier-Flaubert\# - accessed November 12 th 2014

Diderot, D and le Rond d'Alembert, J (eds) Encyclopédie, ou dictionnaire raisonné des sciences, des arts et des métiers, etc (1751-1772), archived online at the University of Chicago: ARTFL Encyclopédie Project (Spring 2013 Edition), Robert Morrissey (ed): http://encyclopedie.uchicago.edu/ - accessed May $15^{\text {th }} 2015$ 
Institut Géographique National (IGN) (1962) (1st édition), Terres Australes et Antarctiques Françaises $(T A A F)$, îles Kerguelen, Carte de Reconnaissance au 100 ooo $^{e ́ m e}, 3$ feuilles, reconnaissance map 1:10o, ooo, 3 sheets

Jastrzebska, J (2014) 'Presqu'île Rollet Park by Atelier Jacqueline Osty and Associes', Landscape Architect Blog: http://landscape4architect.blogspot.com.au/2014/o6/presquile-rollet-park-byatelier.html - accessed February 18th 2015

Lepelley, R (2005) 'Il y a nez et nez : Notes de toponymie', Caen: Annales de Normandie n55:387-402

Loranchet, J (1922) 'Travaux cartographiques de l'expédition de la Curieuse', Paris: La Géographie vXXXVII n1: $26-35$

Morissonneau, C (2008) 'Nommer l'Amérique' in Louder, D and Wadell, E (eds) Franco-Amérique, Silery: Septentrion: $27-39$

Poncin, P (c1910), Géographie (première année), Cours moyen, Paris: Librairie Armand Colin

Rallier du Baty, R (1922) 'Le voyage de la Curieuse (1912-1914)', Paris: La Géographie, vXXXVII nı: 1-26

Raoulx, B (1993) 'Iles du grand large: Analyse comparative à partir de l'exemple des îles Féroé', (unpublished) $\mathrm{PhD}$ thesis, Université de Caen

Tuan, Y-F (1977) Space and Place: The Perspective of Experience, University of Minnesota Press 